\title{
Wybrane zagadnienia dotyczące statusu kobiet w prawie kolonii angielskich w Ameryce Pólnocnej
}

I. Przedstawione w tytule artykułu zagadnienia badawcze stanowią przedmiot analizy w dwóch głównych aspektach, po pierwsze, statusu kobiet w prawie prywatnym, warunkowanym ogólnymi zasadami regulującymi zdolność prawną oraz zdolność do czynności prawnych i po drugie, statusu kobiet w sferze prawa publicznego, w tym także możliwości oddziaływania na sposób sprawowania władzy. Rozważania niniejsze oparto przede wszystkim na metodzie analizy źródeł prawa, a sam artykuł ma charakter przyczynkowy. Materiały źródłowe cytowane $\mathrm{w}$ przypisach zgromadzone zostały w wersji drukowanej podczas kwerendy w Bibliotece Kongresu USA.

Wyjaśnić należy, że osadnicy angielscy w toku procesu kolonizacji uchwalali własne, z czasem coraz bardziej szczegółowe prawa. Regulowały one najczęściej kwestie ustrojowe, a ich treść pozwala na określenie owych aktów prawnych jako quasi-konstytucji. Problematyka prywatno-prawna pozostawała na marginesie legislacyjnych działań kolonistów, co skutkowało bezpośrednim stosowaniem rozwiązań angielskich, zwłaszcza w postaci prawa powszechnego (common law). Dopiero rozwój społeczny przyczyniał się do ujmowania przedmiotowego zagadnienia $\mathrm{w}$ dokumentach kolonialnych zgromadzeń prawodawczych.

Głównym determinantem pozycji prawnej kobiet była przynależność do następujących grup: niewolników, służących kontraktowych lub osób wolnych. Służące kontraktowe z reguły miały ograniczoną zdolność prawną oraz zdolność do czynności prawnych, choć w przypadku służących o wyższym statusie ograniczeniu podlegały jedynie prawa polityczne.

Tak zatem:

1) Status służących kontraktowych często wiązał się z ograniczeniem zdolności prawnej i zdolności do czynności prawnych w okresie sprawowanej służby (np. zakaz zawierania małżeństw, ale zachowanie prawa do dziedzi- 
czenia) i w wielu przypadkach niewiele różnił się od statusu niewolników. Jak zauważyli Beardowie:

Los dziewczyny należącej do służby kontraktowej był szczególnie ciężki. Jeśli postawiła się poza nawiasem społeczeństwa, wydając na świat nieślubne dziecko, bywała karana dodatkowym rokiem lub więcej niewoli $[\ldots]^{1}$.

Są to jednak rozwiązania przeniesione $\mathrm{z}$ Europy i w praktyce często modyfikowane na korzyść służących z uwagi na odrębności społeczne implikowane samym procesem kolonizacji. Pisze o tym I. Rusinowa:

Wielu ludzi dobrowolnie zobowiązywało się odpracować swój przejazd statkiem i w takim przypadku towarzystwo okrętowe bądź kapitan statku 'sprzedawał' ich farmerom czy kupcom potrzebującym siły roboczej. Ci tzw. 'intended servents' po kilku latach stawali się ludźmi wolnymi i często zasiedlali pogranicze².

2) Służący o wyższym statusie mogli otrzymywać wynagrodzenie i korzystać z pełnej zdolności do czynności prawnych w sferze prawa prywatnego, ale pozbawieni byli czynnych i biernych uprawnień wyborczych ${ }^{3}$.

Podobne rozwiązania dotyczyły kobiet na tle tego, czy pozostawały one w związku małżeńskim, jako że wdowy, które nie wyszły ponownie za mąż, oraz panny korzystały z pełnej zdolności do czynności prawnych, ale nie przyznawano im praw wyborczych. Mężatki z kolei poddane były władzy męża, niezależnie od formy zawartego małżeństwa.

Status kobiet-niewolników w prawie kolonialnym stanowi odrębny obszar badawczy wymagający analizy porównawczej źródeł prawa na różnych etapach kolonizacji z wyszczególnieniem kolonii południowych.

Do dziś w kilku stanach USA rozróżnia się „małżeństwa zarejestrowane” (solemnized marriages) - zawarte podług regulacji uwzględnionych w kodeksach rodzinnych oraz „małżeństwa prawa powszechnego” (common law marriages) - uznawane przez prawo, mimo braku ich formalizacji, jeśli spełniają określone przez ustawodawcę przesłanki, np. długotrwałego pożycia i bycia postrzeganym jako małżeństwo we wspólnocie lokalnej.

Ów brak legalizacji stanu faktycznego dotyczył w okresie kolonialnym również rozwodów. Istniejące wówczas kościoły zabraniały tej formy zrywania związku małżeńskiego, a zgromadzenia prawodawcze dysponowały jedy-

${ }^{1}$ A.Ch. Beard, R.M. Beard, Rozwój cywilizacji amerykańskiej, t. 1, Era rolnicza, w przekładzie T. Święckiej, Warszawa 1961, s. 135.

2 I. Rusinowa, Geneza Stanów Zjednoczonych Ameryki Pótnocnej (Unia lat 1774-1783), Warszawa 1974, s. 19-20.

${ }^{3}$ K. Maćkowska, P. Wójcik, Prawne aspekty funkcjonowania rodziny $w$ koloniach angielskich w Ameryce Pótnocnej. Przyczynek do dalszych badań, „Roczniki Nauk Prawnych” 2010, nr 2, s. 102. 
nie prawem do udzielenia zgody na separację „od łoża i stołu”. Dlatego też zdarzało się, że mężczyzna zostawiał kobietę, dając ogłoszenie w prasie, iż nie potrafi z nią żyć ${ }^{4}$. Źródeł tego nie należy szukać w starotestamentowym liście rozwodowym, a jedynie w specyficznych warunkach osadnictwa.

II. Pierwsza refleksja, jaka nasuwa się w kontekście prawa prywatnego, jest taka, że w początkowym okresie zakładania kolonii kobiety miały więcej niezależności w wyborze męża, a $\mathrm{z}$ uwagi na ich niewielką liczbę w praktyce to one decydowały o tym, z kim zawrą związek małżeński. W Krótkim Opisie Prowincji Karolina z 1666 roku (uważa się, że jej autorem był Robert Horne) czytamy:

[...] każda panna i kobieta stanu wolnego, która zamierza udać się w podróż, będzie myślała, że żyje w złotych czasach, w których to mężczyźni wnoszą posag 5 .

Nie stawiano nawet właściwie żadnych wymogów takim potencjalnym osadniczkom i żonom, poprzestając na wskazaniu, by nie miały więcej niż 50 lat. W związku z brakiem kobiet na obszarze kolonii, Kompania Wirginii po raz pierwszy w $1620 \mathrm{r}$. zorganizowała przedsięwzięcie polegające na wyborze 90 dziewcząt pochodzących z tzw. dobrych domów i przetransportowaniu ich jako kandydatek na żony do Wirginii. Wybór przez mężczyznę musiał zyskać aprobatę samej kandydatki. Taki początek małżeństwa wiązał się z wykupieniem, czyli zapłaceniem Kompanii 120 funtów tytoniu (jeden funt kosztował 3 szylingi), co stanowiło wówczas dość wysoką cenę. Niemniej, przedsięwzięcie to cieszyło się dużą popularnością, tak zatem rok później przysłano kolejnych 60 dziewcząt, których cena wynosiła już 150 funtów tytoniu ${ }^{6}$. Znany w literaturze jest przykład założyciela Springfield w Massachusetts, Williama Pynchona, który szybko owdowiał i dość długo nie żenił się ponownie z braku odpowiednich niezamężnych kobiet, do czasu gdy poślubił poważną matronę z Doxbury, która zdążyła pochować już dwóch mężów ${ }^{7}$. W rzeczywistości jednak posag wnosiły kobiety, a prawo do niego stanowiło dla nich jedyne zabezpieczenie materialne w przypadku skazania męża na karę konfiskaty majątku. W rejestrze kolonialnym Marylandu odnajdujemy przypadek Pani Smith, której mąż został uznany w 1637 r. winnym przestępstwa piractwa, za co miał zostać powieszony, a jego majątek przepadał na rzecz skarbu kolonialnego, a konkretnie właścicieli kolonii. Konfiskata nie dotyczyła wła-

4 Tamże, s. 107-108.

5 A Brief Description of the Province of Carolina (1666), [w:] H.T. Lefler, North Carolina History Told By Contemporaries, Chapel Hill 1948, s. 22.

6 J. Grahame, The History of the United States of North America, t. 1, From the plantation of the British colonies till their assumption of national independence, Boston 1845, s. 71. O.P. Chitwood, A history of colonial America, New York 1948, s. 80-81.

7 S.E. Morison, Builders of the Bay Colony, Boston 1964, s. 340. 
śnie majątku stanowiącego posag ${ }^{8}$. Z czasem stabilizacja społeczna wynikająca m.in. z rosnącej liczby kobiet (z rejestru gminy Exeter wynika, iż w 1775 r. zamieszkiwało ją 324 mężczyzn między 16 a 50 rokiem życia i 892 kobiet - w tym dzieci płci żeńskiej ${ }^{9}$ ) prowadziła do ugruntowania się zwyczajowych $\mathrm{w}$ tej sferze praw angielskich, jak np. składanie przez mężczyznę propozycji zawarcia związku małżeńskiego rodzicom kandydatki na żonę ${ }^{10}$. W Nowej Anglii istniał zwyczaj - co dziwiło podróżującego po koloniach w 1759 r. angielskiego duchownego, Andrew Burnaby'ego - pozostawania narzeczonych przez noc w jednym łożu, po czym strony ostatecznie decydowały o zawarciu małżeństwa ${ }^{11}$. Zdumienie Burnaby'ego samo z siebie jest wszak zadziwiające, gdyż zwyczaj ten ma swoje korzenie w prawie angielskim, więc nie stanowił on praktyki, która wykształciła się na terenie kolonii. Wydaje się jednak, iż nowoangielski purytanizm sprzyjał ograniczeniu statusu kobiet w osobowym prawie prywatnym, zwłaszcza w kwestiach subtelnych moralnie. Z kolei w literaturze często podaje się informację, iż w Marylandzie 1/3 panien młodych nieurodzonych w kolonii była w ciąży w czasie zawarcia małżeństwa ${ }^{12}$. Nie można zgodzić się z poglądem, iż wynikało to z braku prawnej regulacji dotyczących obyczajności, bowiem tych było sporo także i w koloniach południowych. W przeciwieństwie do osad północnych kładziono po prostu mniejszy nacisk na ich przestrzeganie. Tolerancja w stosunku do naruszenia norm zarówno moralnych, jak i prawnych była niewątpliwie sankcjonowana potrzebą społeczną. To właśnie rejon Zatoki Chesapeake charakteryzował się aż do schyłku XVII wieku przewagą kawalerów nad liczbą rodzin ${ }^{13}$, gdyż inaczej niż w kongregacjach Zatoki Massachusetts względy religijne nie powodowały imigracji całych rodzin. Nowoangielskie prawo kolonialne potwierdzało obowiązujący w metropolii wymóg posłuszeństwa i podporządkowania żony mężowi, tyle że ustawowo zniesiono tu obowiązujący w metropolii zwyczaj karania, w tym bicia żon. Według Zwodu Praw Massachusetts:

Każda zamężna kobieta będzie wolna od kar cielesnych lub chłosty wykonywanych przez jej męża, chyba że nastąpi to w jego obronie własnej wskutek jej

${ }^{8}$ Archives of Maryland. Reprint pod red. W.H. Browna, Baltimore 1883, s. 17.

${ }^{9}$ Ch.H. Bell, History of the Town of Exeter, New Hampshire, Exeter 1886, s. 88.

${ }^{10}$ Kiedy zaś kobiet było już więcej, owe ,złote czasy” się skończyły, przynajmniej na terenie wschodnich kolonii. Jak zauważył W. Wayda, jedną z miejskich rozrywek było oglądanie palenia na stosach czarownic i publicznej chłosty kobiet, [w:] tenże, Historia Stanów Zjednoczonych Ameryki Pótnocnej, Chicago 1922, s. 105.

${ }_{11}$ P. Smith, A People's History of the American Revolution, t. I, A New Age Now Begins, New York-St. Louis-San Francisco 1976, s. 69.

12 Zob. E.H. Monkkonen, The Colonies and Early Republic, t. I, Westport-Londyn 1934, s. 240 .

13 G.L. Main, Ineaquality in Early America: The Evidence from Probate Records of Massachusetts and Maryland, „Journal of Interdisciplinary History” 1977, nr 4, s. 564. 
ataku. Jeśli pojawi się słuszna przyczyna kary, skargę złoży się do władz zgromadzonych w którymś z sądów, tylko od którego ona ją [karę - K.M.] otrzyma ${ }^{14}$.

Kobiety mogły tu ponadto domagać się rozwodu na podstawie opuszczenia ich przez męża lub doznanego okrucieństwa. W jednym z listów z $1640 \mathrm{r}$. skierowanym do gubernatora Massachusetts Winthropa, mieszkańcy Portsmouth zaznaczyli, że pewna mieszkanka jest niewinna w sprawie, w której jej mąż oskarżył ją o przyczynienie się do awantury, wskutek czego za obelżywe słowa i przekleństwa zakłócające ciszę „w czasie, kiedy inni pozostają już w łóżkach”, ukarano go dybami. Potwierdzili oni również, że mężczyzna ten znany jest $z$ agresywnych zachowań, a jego żona, mimo tego, trwała przy nim i w efekcie uznali, że zachowanie jej męża jest wystarczającym wytłumaczeniem dla nieuwolnienia go $\mathrm{z}$ dybów po upływie wyznaczonego terminu odbywania tej kary ${ }^{15}$. Podkreślenia jednak wymaga, że kobiety ponosiły odpowiedzialność karno-prawną za bicie i lżenie swoich mężów i nakłanianie dzieci do wspierania ich w tych aktach agresji - jak to zostało sformułowane w niektórych źródłach ${ }^{16}$.

Pewne zrównanie w prawie nastąpiło w ujednoliceniu znamion za popełnienie przestępstwa cudzołóstwa dla obu płci. Tak zatem nie tylko mężatka, ale również żonaty mężczyzna był $\mathrm{w}$ tym przypadku pociągany do odpowiedzialności i otrzymywał tę samą karę ${ }^{17}$. Nie dotyczyło to oczywiście służących kontraktowych, które za urodzenie nieślubnego dziecka musiały pozostać dłużej na służbie, a ojciec dziecka, jeśli był panem służącej, ponosił drobną karę finansową. Warto dodać, iż w niektórych koloniach południowych, w związku z niewielką liczbą duchownych, odstępowano od kościelnej formy zawarcia małżeństwa, a zgodnie z obowiązującym prawem - o czym w oparciu o Polityczne Roczniki Stanów Zjednoczonych (Political Annals of the United States) pisał G. Chalmers ${ }^{18}$ - zawarcie małżeństwa odbywało się przed gubernatorem i radą w obecności świadków. Stopniowo, wraz ze zwiększającą się liczbą duchownych, ograniczano możliwość zawierania małżeństw w świeckiej formie. Przykładowo, w Karolinie Północnej uchwalono w 1741 roku ustawę zezwalającą na wstępowanie w związek małżeński przed sędzią pokoju jedynie w przypadku braku duchownego zamieszkującego w danym

14 Art. 80, Massachusetts Body of Liberties, [w:] D.S. Lutz, Colonial Origins of the American Constitution. A Documentary History, Indianapolis 1998, s. 81.

15 Tekst listu zamieszczony [w:] H.M. Chapin, Documentary History of Rhode Island, t. II, Providence 1919, s. 173-174.

16 S. Botein, Early American Law and Society, New York 1983, s. 42.

17 Tamże.

18 G. Chalmers, Political Annals of the Province of Carolina, [w:] Historical Collections of South Carolina; Embracing Many Rare and Valuable Pamphlets, and other Documents, Relating to the History of that State, from its Discovery to its Independence, in the Year 1776, pod red. B.R. Carroll, t. II, New York 1836, s. 291. 
okręgu, ewentualnie za jego zgodą ${ }^{19}$. Trzeba też dodać, iż w ustawodawstwie kolonialnym można znaleźć przepisy dotyczące zakazu zawierania małżeństw z osobami niewolnymi, które były adresowane wyłącznie do wolnych kobiet. Ustawa zgromadzenia kolonialnego Marylandu z 1664 roku regulowała, iż wskutek naruszenia takiego zakazu kobieta będzie służyć do śmierci męża jego panu, a dzieci zrodzone $\mathrm{z}$ owego związku pozostaną tam na służbie do ukończenia 30. roku życia ${ }^{20}$.

Jako ciekawostkę warto wskazać opis Karoliny Johna Lawsona opublikowany w 1709 r., w którym znajduje się fragment zachwalający kobiety mieszkające na obszarze tej kolonii, a mianowicie: rodzą wiele dzieci, świetnie pływają czółnami, $\mathrm{z}$ entuzjazmem pomagają mężom w pracy na plantacjach, a ich córki otrzymują wszechstronne wykształcenie związane z prowadzeniem gospodarstwa (nie tylko nabywają umiejętność szycia i pracy przy kołowrotku $)^{21}$.

Podobnie jak w Europie różne bywały w stosunku do kobiet sankcje za naruszenie porządku publicznego. Przykładowo, w Marylandzie zdradę rozumianą nie tylko jako przestępstwa przeciwko władzy kolonialnej, ale i władcom angielskim - karano w przypadku mężczyzn powieszeniem i poćwiartowaniem, a w przypadku kobiet spaleniem ${ }^{22}$.

Same osadniczki akceptowały, panujące w Anglii i w dużej mierze przenoszone za ocean, przekonanie o ich „niższości”, wyrażające się „,drobniejszą postacią, pośledniejszym umysłem oraz bardziej wybujałymi uczuciami i psychicznym uzależnieniem" "23. Większość też podzielała pogląd siostry Johna Winthropa - gubernatora Massachussetts, który ta wyraziła w liście do brata: „Jestem tylko żoną, starczy więc, że będę spełniała wolę męża”24.

Kobiety w kolonialnym świecie Ameryki Północnej miały większą swobodę w zakresie prawa rzeczowego. Fakt, że przeżywały swoich mężów, zyskał zwyczajową i prawną akceptację dla sprawowania zarządu nad odziedziczonym majątkiem. To niestety z czasem w pewnym stopniu obróciło się przeciwko nim. Rozwój demograficzny kolonii skutkował bowiem deficytem ziemi, nie tylko w znaczeniu korporacyjnym, a zatem na potrzeby wykonywania publicznych zadań lokalnych, ale także w znaczeniu prywatno-prawnym. Długo żyjące zarządczynie majątków ,przeszkadzały” młodszemu pokoleniu $\mathrm{W}$ materialnym usamodzielnieniu się. W cieniu niektórych oskarżeń o czary stały właśnie próby odsunięcia od władzy starszych członków rodziny w celu uzyskania samodzielnej własności nieruchomo-

\footnotetext{
19 An Act Concerning Marriages (1741), [w:] H.T. Lefler, op. cit., s. 47.

20 An Act Concerning Negroes and Other Slaves, [w:] S. Botein, op. cit., s. 75.

21 J. Lawson, New Voyage to Carolina (1709), [w:] H.T. Lefler, op. cit., s. 38.

${ }^{22}$ Archives of Maryland, s. 71.

23 G.B. Tindall, D.E. Shi, op. cit., s. 108.

24 Tamże.
} 
ści ${ }^{25}$. Warto też dodać za M. Rozbickim, że owe wdowy, które wzbogaciły się dzięki swego rodzaju cyklowi odpowiednich zamążpójść, stały się z czasem ,przynętą” dla angielskich nieposesjonatów. U schyłku XVII wieku na deskach londyńskiego teatru wystawiano popularną komedię, zatytułowaną Wdowa Ranter, w której bohaterem jest młodszy syn dżentelmena, który udał się do Wirginii w nadziei na poślubienie bogatej wdowy i czeka, aż z ziemskiego padołu odejdzie mąż upatrzonej Pani Ranter ${ }^{26}$. Sama Pani Ranter przybyła do kolonii jako służąca kontraktowa, która zaczęła tworzyć fortunę dzięki małżeństwu ze swoim panem. Pije alkohol, przeklina i przebrana za mężczyznę uczestniczy w rebelii Bacona przeciwko gubernatorowi Berkeleyowi. Miała później swoją faktyczną naśladowczynię Debory Sampson, która przyłączyła się do pułku z Massachusetts i służyła w nim w latach 1781-1783 jako Robert Schurtleff ${ }^{27}$. Z drugiej strony, powszechny fakt zarządzania majątkiem przez kobiety implikował zdarzające się przypadki unieważniania testamentów w przypadku pozbawienia wdowy należytej części spadku ${ }^{28}$. Zasadniczo jednak początkowa w procesie kolonizacyjnym konieczność ściągnięcia osadników sprzyjała względnemu otwarciu dostępu do ziemi i niekiedy zrównaniu w tym zakresie praw mężczyzn i kobiet. Autor XVII-wiecznego Opisu Prowincji Karolina w Ameryce (An Account of the Province of Carolina, in America) wskazał na następujące kryteria przyznawania działek w Karolinie (zanim nastąpił podział na część południową i północną): wolni mężczyźni (freemen) i ich żony oraz wolne kobiety (freewomen), panowie i panie rodzin (masters and mistress of family) otrzymywali podstawowe 50 akrów (z rejestru kolonialnego wynika, iż początkowo było to 60 akrów) i tyle samo za każdego sprowadzonego wolnego mężczyznę lub służącego oraz za każdą kobietę lub służącą zdolną do zawarcia małżeństwa. Przydział za dzieci i służących poniżej 16 roku życia wynosił 40 akrów $^{29}$. Jak wynika z powyższego, status kobiety jako mężatki lub stanu wolnego nie miał żadnego znaczenia. W rejestrze kolonialnym opisany jest rzadki przypadek z 1713 r., w którym Catha Hyde pod przysięgą potwierdziła przed zarządem kolonialnym fakt sprowadzenia do kolonii 8 osób $^{30}$. W Koncesji właścicieli New Jersey wydanej w 1664 r.

${ }^{25} \mathrm{O}$ innym ekonomicznym podłożu tych procesów piszą: P. Boyer, S. Nissenbaum, Salem Possessed: The Social Origins of Witchcraft, [w:] Colonial America. Essays in Politics and Social Development, New York 1983, s. 343-372.

${ }^{26}$ M. Rozbicki, Narodziny Narodu. Historia Stanów Zjednoczonych do 1861 roku, Warszawa 1991, s. 75.

27 G.B. Tindall, D.E. Shi, op. cit., s. 241.

28 S. Botein, op. cit., s. 43.

${ }^{29}$ S. Wilson, An Account of the Province of Carolina, in America: Together with an Abstract of the Patent, Londyn 1682, [w:] Historical Collections..., s. 31.

${ }^{30}$ The Colonial Records of North Carolina. Reprint pod red. W.L. Saundersa, Raleigh 1886, s. 3. 
także mamy do czynienia $\mathrm{z}$ równouprawnieniem kobiet i mężczyzn w kwestii nadawania ziemi, tyle że w tym przypadku jej wielkość zależała od czasu przybycia do kolonii. Im szybciej to nastąpiło, tym więcej akrów nadawano, począwszy od 120 , a kończąc na $40^{31}$. Zdarzało się zatem często, że status kobiet nie pogarszał się po śmierci mężów. Przykładowo, wdowa po pierwszym młynarzu w Providence zawarła $\mathrm{z}$ gminą umowę dotyczącą kontynuacji prowadzenia przez nią młyna. Kiedy dorósł najstarszy syn, to on przejął ową działalność, po jego zaś śmierci to jego żona odziedziczyła dom oraz młyn, a najstarszy syn otrzymał w spadku więcej ziemi od swego rodzeństwa pod warunkiem, iż będzie pomagał matce je wychowywać. Dwie córki odziedziczyły po 40 akrów ziemi każda, a cały majątek obejmował 300 akrów $^{32}$. W niektórych dokumentach kolonialnych wyraźnie regulowano prawo kobiet do dziedziczenia po mężu 1/3 wszystkich nieruchomości oprócz odrębnie nabywanego w spadku prawa do domu.

Ciekawy przypadek stanowi niewątpliwie purytański zakaz noszenia ozdób i biżuterii przez osoby, które na podstawie wysokości płaconych podatków nie zaliczają się do wyższej klasy społecznej. W Newburry na przykład umorzono postępowanie wobec dwóch kobiet noszących posrebrzane szale i kaptury nieadekwatnie do zajmowanej przez nie pozycji społecznej po tym, jak udowodniły, iż majątek ich mężów jest warty 200 funtów każdy ${ }^{33}$.

Na próżno też poszukiwać nazwisk kobiet w rejestrze gminy Cambridge w Massachusetts, w protokołach zebrań gminnych oraz zebrań członków zarządu gminnego. W kontekście nadawanych licencji oraz pozwoleń na korzystanie ze wspólnego drewna czy kamieni z rzadka pojawiają się nazwiska wdów. W 1689 r. odbyło się tam jedno ze spotkań właścicieli kamieniołomu dotyczące przeznaczenia części budulca, a wśród głosujących odnajdujemy tam nazwiska dwóch wdów i jednej zamężnej kobiety ${ }^{34}$.

Trudna sytuacja dla zamężnej kobiety pojawiała się wskutek porzucenia jej przez męża w związku z opuszczeniem przez niego danej jednostki lokalnej lub w ogóle kolonii. Przyjmowanie nowych mieszkańców oraz przeprowadzenie się poza granice lokalitetu wymagało zgody władz lokalnych. W rejestrze gminy Providence można odnaleźć kazus Marry Walling z 1662 r., której mąż przeniósł się do innej gminy. Zebranie gminne na jej prośbę wyznaczyło nowego opiekuna prawnego dla sieroty, którą Thomas Walling zajmował się, gdy mieszkał w Providence, a sąd sesji kwartalnej wydał zakaz dokonywania czynności prawnych rozporządzających majątkiem (a więc „ku-

31 The Concessions and Agreement of the Lord Proprietors of the Province of New Jersey (1664), [w:] J.P. Boyd, Fundamental Laws and Constitutions of New Jersey 1664-1964, New York-Toronto-London 1964, s. 61.

32 G.S. Kimball, Providence in Colonial Times, New York 1972, s. 41-42.

33 Th.J. Wertenbaker, The First Americans 1607-1690, New York 1969, s. 73.

34 The Records of the Town of Cambridge, Massachusetts 1630-1703, s. 291. 
powania od niej rzeczy i handlowania z nią") bez zgody gminy ${ }^{35}$. Inny przykład dotyczący rozporządzania majątkiem przez kobiety to fragment dotyczący ksiąg wieczystych, w którym w 1671 r. wdowa Mary Mawrey sprzedała majątek, pełniąc na mocy ustanowienia przez radę gminną funkcję zarządcy ${ }^{36}$. Nie zawsze jednak prawo zarządu majątkiem przekazywano wdowom. To bowiem najczęściej wiązało się z testamentem pozostawionym przez męża. Jeśli testament nie został sporządzony, zarząd nad spadkiem sprawował właściwy organ lokalny (np. rada gminy). Według nowojorskiej Karty Wolności i Przywilejów z 30 października 1683 r. (Charter of Liberties and Privileges):

Wdowa po śmierci swego męża otrzyma wniesiony przez siebie posag i będzie, co może uczynić, zamieszkiwać w głównej części domu swego męża czterdzieści dni po śmierci swego męża, w ciągu których to czterdziestu dni posag zostanie jej przydzielony, a do jej posagu przypisze się trzecią część wszystkich ziem jej męża nabytą $\mathrm{w}$ trakcie trwania małżeństwa, chyba że przyznano jej mniej przed zawarciem małżeństwa ${ }^{37}$.

W pierwszej połowie XVIII wieku rozwój miast przyczynił się do zmiany społecznej roli wdowy z ewentualnej zarządczyni majątkiem na podmiot w pełni uczestniczący w życiu gospodarczym. W efekcie tego zaczęły domagać się one prawnych instrumentów wpływania na politykę miejską. Jedną $\mathrm{z}$ form głoszenia tych postulatów stanowiły ogłoszenia w prasie. W Nowym Jorku na przykład wdowy zamieściły w 1733 r. w nowojorskiej gazecie następującą notę:

[...] Jesteśmy gospodyniami domowymi, płacimy podatki, zajmujemy się handlem i większość z nas jest kupczyniami, a skoro w dużej mierze mamy swój wkład we wspieraniu rządu, powinnyśmy być uprawnione do pewnych korzyści $\mathrm{z}$ tego $[\ldots]^{38}$.

III. Kobiety przez cały okres kolonialny nie miały praw politycznych, co w większości regulacji prawnych nie oznaczało wyraźnego zaakcentowania, lecz miało charakter dorozumiany.

W literaturze przedmiotu podkreśla się edukacyjny walor wychowywania dziewcząt w protestanckich rodzinach Nowej Anglii jako czynnika sprzyjającego emancypacji kobiet $\mathrm{w}$ wiekach późniejszych ${ }^{39}$. Zjawisko to nie miało,

${ }^{35}$ The Early Records of the Town of Providence, t. II. Reprint wydany w Providence w 1893 r., s. 33.

36 Tamże, s. 209.

${ }^{37}$ Charter of Liberties and Privileges, [w:] D.S. Lutz, op. cit., s. 260.

${ }^{38}$ Cyt. za: P. Smith, A People's History of the American Revolution, t. 1, A New Age Now Begins, New York i in., s. 77. Zob. także K. Maćkowska, P. Wójcik, op. cit., s. 113-114.

${ }^{39}$ P. Smith, op. cit., s. 72-73. 
rzecz jasna, bezpośredniego wpływu na nadanie kobietom praw politycznych, gdyż taka autonomia nie leżała w purytańskim modelu porządku publicznego, niemniej staranne wykształcenie kształtowało w trakcie pokoleń większą niezależność kobiet.

Mimo braku praw politycznych zdarzały się przypadki pełnienia przez kobiety ważnych ról w porządku ustrojowym kolonii. Niewątpliwie dotyczyło to Ann Hutchinson, uczennicy Johna Cottona, która ze względów religijnych przybyła do Bostonu w 1634 r. Organizowała ona w każdy czwartek w swoim domu spotkania dla zamężnych i zajętych prowadzeniem domów kobiet, podczas których wykładała im istotę niedzielnych nabożeństw ${ }^{40}$. Początkowo cieszyło się to akceptacją władz kolonii, a z takich lekcji korzystało kilkadziesiąt kobiet. Później, gdy poglądy wygłaszane przez Ann Hutchinson nabrały charakteru dysydenckiego (krytykowała doktrynę predestynacji), kobietę $\mathrm{w}$ niełatwym zresztą procesie skazano na wygnanie. Wielkim wrogiem Hutchinson był gubernator Massachusetts, John Winthrop. Znana w literaturze jest wymiana zdań w procesie między nim a oskarżoną. Na zarzut, iż naucza w domu, podała kilka cytatów z Biblii dotyczących obowiązku nauczania młodszych przez starszych, co Winthrop skwitował stwierdzeniem, iż fragmenty nie odnoszą się do jej konkretnej sytuacji. Wówczas Hutchinson błyskotliwie odpowiedziała, iż chyba nie musi pokazać swojego nazwiska w cytatach. Replika Winthropa, iż nie zamierza dyskutować z osobą jej płci ${ }^{41}$, stanowi znamienne podsumowanie roli kobiet w kolonialnym społeczeństwie. W literaturze podkreśla się, iż zapalczywość władz kolonii w oskarżaniu Hutchinson wiązała się właśnie z jej płcią, bo przecież w przypadku innego dysydenta Rogera Williamsa sam gubernator zaangażował się w zorganizowanie jego ucieczki z więzienia. Winthrop w swych dziennikach wspominał jeszcze o jednej mieszkance pochodzącej z wyższych warstw społecznych, lady Deborze Moody z Salem, również ekskomunikowanej i skazanej na wygnanie w związku - jak to określił Winthrop - ,zarażeniem się anabaptyzmem"42.

Niewątpliwie największym paradoksem w sferze praw politycznych kobiet był art. 4 pierwszej konstytucji stanowej New Jersey z 1776 roku, który przyznawał bierne prawo wyborcze wszystkim mieszkańcom posiadającym majątek o wartości 50 funtów i zamieszkującym kolonię przez rok poprzedzający wybory. Rzecz jasna, celem ustrojodawcy nie było rozszerzenie praw wyborczych. Cenzus płci wydawał się bowiem tak oczywisty, iż po prostu nie wyrażono go wprost. $\mathrm{Z}$ tego względu na mocy tej konstytucji z praw wybor-

${ }^{40} \mathrm{Na}$ ten temat zob. C.P. Nettels, The Roots of American Civilization. A History of Colonial Life, New York 1938, s. 178.

${ }^{41}$ Proces ten opisuje m.in. M. Rozbicki, op. cit., s. 142-143.

42 J. Winthrop, History of New England. Reprint pod red. J.K. Hosmera, Winthrop's Journal "History of New England" 1630-1649, t. II, New York 1845, s. 126. 
czych korzystały i kobiety, i czarnoskórzy mieszkańcy. Dopiero w 1807 roku uchwalono poprawkę pozbawiającą ich praw wyborczych ${ }^{43}$. Zaistniały w powyższym przypadku problem wynikał bezpośrednio z użycia terminu ,mieszkańca" zamiast powszechnie używanego w dokumentach kolonialnych pojęcia „freemana”, który - mimo ogólnego znaczenia jako wolnego człowieka - odnosił się właśnie do mężczyzn. W niektórych dokumentach lokalnych kontekście praw wyborczych używano także pojęcia mężczyzny, a w Wirginii wyraźnie wyłączano kobiety z grupy mającej prawa polityczne, używając np. sformułowania, iż żadna kobieta, ani wolna, ani mężatka, mimo że ma status freeholdera, nie będzie miała głosu w wyborach przedstawicieli do kolonialnego ciała ustawodawczego ${ }^{44}$.

G.B. Tindall i D.E. Shi wspominają ponadto o Margaret Brent, która w 1638 r. przybyła z braćmi do Marylandu i tak dobrze zarządzała plantacją swoją, jak gospodarstwami braci, iż sam gubernator powierzył jej administrację własnym majątkiem, z którego to zadania Pani Brent wywiązała się doskonale, uporządkowała interesy mocodawcy, sfinansowała lokalną milicję, stłumiła lokalną rewoltę, a następnie zażądała prawa głosu w zgromadzeniu kolonialnym. Gubernator oczywiście docenił jej ogromne zasługi, ale prośbie odmówit ${ }^{45}$.

Warto nadmienić, iż znaną sufrażystką była żona Johna Adamsa, Abigail, która wręcz żądała od męża, aby w ramach tworzonego porządku konstytucyjnego nie zapomnieć o kobietach. Żaden jednak z twórców nowego państwa nie był obrońcą politycznych praw kobiet.

IV. Mimo braku dostępu do wyższego wykształcenia, praktyczne potrzeby otwierały kobietom drogę do wielu zawodów, w tradycji europejskiej zarezerwowanych dla mężczyzn: nauczyciela, prawnika, właściciela sklepów i tawern, szewca, kowala, łowcy, rusznikarza czy fryzjera ${ }^{46}$. Kiedy na przykład zgromadzenie kolonialne Rhode Island nadało w $1681 \mathrm{r}$. zebraniom gminnym prawo do regulowania i licencjonowania sprzedaży mocnego alkoholu, to licencję na prowadzenie karczmy otrzymała Mary Pray. Opłata za licencję wynosiła 20 szylingów, co stanowiło sporą kwotę. Dlatego w zamian za jej uiszczanie, Mary Pray zaproponowała, iż zebrania gminne będą odbywały się w jej domu. Po jej śmierci licencję przejął jej syn ${ }^{47}$. Kobiety też mogły na równi z mężczyznami zostać uprawnione do handlu z Indianami. W rejestrze kolonialnym Marylandu zapisano, iż „mieszkańcy” kolonii (a zatem mężczyźni i kobiety) mogli dokonywać transakcji z Indianami tylko na podstawie

\footnotetext{
${ }^{43}$ J.P. Boyd, op. cit., s. 31.

${ }^{44}$ C.F. Bishop, History of elections in the American colonies, New York 1983, s. 64.

${ }^{45}$ G.B. Tindall, D.E. Shi, op. cit., s. 110.

46 P. Smith, op. cit., s. 73-74.

${ }^{47}$ G.S. Kimball, op. cit., s. 126-127.
} 
licencji wydawanej przez gubernatora lub sekretarza kolonii ${ }^{48}$. Niemniej kobiety zajmowały się również bardziej delikatnymi, a zarazem intelektualnymi zajęciami, jak choćby pierwsza amerykańska poetka, Ann Dudley Bradstreet z Salem, żona byłego gubernatora Massachusetts, która zmarła w $1713 \mathrm{r}$. w wieku 79 lat ${ }^{49}$.

Przypomnienia w tym miejscu wymaga, iż jeden z rozłamów partii demokratycznej nastąpił wskutek społecznego ostracyzmu kierowanego przez członków gabinetu Jacksona i ich żon w stosunku do żony sekretarza wojny Johna Eatona. Ten bowiem poślubił wdowę, córkę karczmarza słynącą ze swobodnego stylu życia. Jackson podejrzewał Calhouna o udział w podżeganiu do ignorowania Peggy Eaton w celu zdyskredytowania jego administracji ${ }^{50}$.

Inne małżeństwo, które przyczyniło się do politycznych niesnasek, to związek indiańskiej księżniczki Pocahontas i Johna Rolfe’a. Księżniczka znana już była kolonistom w związku z rzekomym uratowaniem życia kapitanowi Johnowi Smithowi, jednemu z założycieli Wirginii. Po tym zaś, jak została porwana dla okupu, pierwszy plantator tytoniowy, John Rolfe poprosił o jej rękę, aby uratować kruchy pokój z Indianami ${ }^{51}$. Jak w XVIII wieku podał W. Stith, kiedy Pocahontas, zwana już lady Rebeką, udała się z mężem w podróż do metropolii, jako osoba ,ucywilizowana na sposób angielski” i znająca język była zapraszana na liczne bale i przyjęcia, a to powszechne zainteresowanie przykuło uwagę także i władcy angielskiego, który zaczął obawiać się, czy poprzez to małżeństwo kapitan Rolfe nie zechce wykazywać się prawami do kolonialnych ziem ${ }^{52}$.

V. Nie ulega wątpliwości, że swoboda pierwszych kobiet osadniczek była większa w porównaniu do ich statusu w krajach pochodzenia i miała najpierw charakter faktyczny, a następnie zyskiwała potwierdzenie w ustawodawstwie kolonialnym. Co więcej, zjawisko to towarzyszyło postępowi kolonizacji na obszarze północno-zachodnim, a następnie również rozwojowi osadnictwa zachodniego, dokonywanego już pod auspicjami władzy federalnej.

Podnieść przy tym należy, że rozszerzenie prywatnych i publicznych uprawnień dotyczyło wyłącznie wolnych kobiet, a praktyczne, w tym przede wszystkim społeczne potrzeby przyczyniały się bądź do prawnego stopniowego zrównywania statusu kobiet z pozycją mężczyzn lub nieprzestrzegania norm prawnych ograniczających uprawnienia kobiet.

48 Archives of Maryland..., s. 44.

49 F.D. Robotti, Chronicles of Old Salem. A History in Miniature, Salem 1948, s. 32.

50 A.M. Schlesinger, Political and Social History of the United States 1829-1925, s. 31-32.

51 G.B. Tindall, D.E. Shi, op. cit., s. 62.

52 W. Stith, The History of the First Discovery and Settlement of Virginia. Reprint z 1969 r., New York-Londyn, s. 143. 
Zauważyć należy, że w rejestrach kolonialnych dotyczących władzy publicznej pojawia się znikoma liczba kobiet, a ich nazwiska wymieniane są w kontekście otrzymywanych licencji lub zaległości podatkowych, za wyjątkiem Ann Hutchinson i jej teologiczno-politycznej działalności.

$\mathrm{Na}$ koniec zaakcentować warto, że pierwsze zorganizowane ruchy na rzecz obrony politycznych praw kobiet pojawily się w XIX wieku. W $1848 \mathrm{r}$. opublikowano parafrazę Deklaracji Niepodległości, zwaną Deklaracją Zapatrywań (Declaration of Sentiments) głoszącą równość kobiet i mężczyzn i będącej wynikiem konwencji zebranej przez kobiety w Seneca Falls w Pensylwanii ${ }^{53}$. W 1839 r. Mississippi jako pierwszy stan przyznało kobietom zamężnym kontrolę nad ich własnością, a w 1869 r. terytorium Wyoming jako pierwsze przyznało kobietom pełne prawa wyborcze (a następnie, Kolorado, Utah i Idaho). Federalna zaś Poprawka zrównująca status kobiet i mężczyzn została przyjęta w 1920 roku.

\section{THE STATUS OF WOMEN UNDER THE LAWS OF ENGLISH COLONIES IN NORTH AMERICA}

\section{Summary}

This article embraces selected issues related to the legal status of women in English colonies of North America. This subject has been widely researched and this article is meant to be a contributory one.

The legal status of women in colonial America has been presented in the aspect of private and public law. The most important criterion determining their legal position was affinity to a social group (slaves, servants or free women). The relatively small number of women who initially inhabited colonies had also contributed to their greater autonomy in social life.

Differences in the legal status of women in New England and in other colonies resulted from different legal systems and religion. Northern colonies were populated by families which had migrated from Europe and were characterized by stability. The fact that girls in northern colonies received better education is also recognised as a factor responsible for their subsequent emancipation.

Quasi-constitutions of all colonies directly or indirectly denied women voting rights. However, socially accepted cases of an authentic influence of wealthy women on colonial governmental institutions were not so rare. The reason for that was that the building of the New World demanded from women to be active in fields traditionally reserved for men, which consequently led to their autonomy and gradually became confirmed in colonial documents modifying English common law.

53 Szerz. zob.: G.B. Tindall, D.E. Shi, op. cit., s. 489. 


\title{
LE STATUT DE LA FEMME DANS LE DROIT APPLICABLE SUR LE TERRITOIRE DES COLONIES ANGLAISES EN AMÉRIQUE DU NORD
}

\begin{abstract}
Résumé
Le présent article contient des réflexions sur le statut de la femme dans le droit applicable sur le territoire des colonies anglaises en Amérique du Nord. La situation juridique des femmes est présentée sous deux aspects majeurs: le droit privé et le droit public. L'un des critères fondamentaux qui détermine la position de la femme est l'appartenance aux groupes suivants: esclaves, bonnes (employées de maison) travaillant sur la base d'un contrat ou personnes libres. Les facteurs démographiques et, plus précisément, le nombre peu élevé des premières femmes colons, font augmenter formellement l'autonomie des femmes ou tout simplement modèrent l'exécution de la législation en vigueur. Les différences au niveau de statut de la femme observables entre le droit en application en Nouvelle Angleterre et des régulations en vigueur dans d'autres colonies, résultent des aspects religieux. La construction des colonies plus orthodoxes du Nord est basée sur des familles entières d'imigrants venues d'Europe, d'où leur plus grande solidité. En outre, la pression faite par les sociétés puritaines sur l'éducation globale des filles sera considérée dans la littérature traitant le sujet comme l'un des facteurs stimulant l'émancipation. Les actes quasi-constitutifs de l'ensemble des colonies contiennent des dispositions qui refusent explicitement ou implicitement à la femme le droit de vote. Toutefois, il arrive à l'époque de voir les cas de figure acceptés par la société où l'on peut remarquer une influence réelle des femmes riches sur les institutions coloniales détenant le pouvoir. Cela résultait du fait que la construction du Nouveau Monde demandait aux femmes d'être actives dans les domaines réservés historiquement aux hommes, ce qui leur donne finalement plus de latitude par rapport, en tout cas, au statut de la femme dans les pays d'origine. Cet état des choses sera confirmé par les normes coutumières modifiées.
\end{abstract}

